\title{
The setting of the Split-IP parameter in Afrikaans: Evidence from transitive expletive constructions and object shift constructions ${ }^{1}$
}

\author{
Simone Conradie \\ Department of General Linguistics, Stellenbosch University, 7600 Stellenbosch, South Africa \\ E-mail: sconra@sun.ac.za
}

\section{Introduction}

Bobaljik and Thráinsson (1998) showed how the Split-IP parameter (SIP) (Thráinsson 1996) could account for the cross-linguistic clustering of a number of superficially unrelated properties: multiple inflectional morphemes, transitive expletive constructions (TECs), object shift constructions (OSCs), and verb movement in non-V2 environments. This paper investigates the setting of the SIP in Afrikaans. It will be shown that the only two diagnostics that can be used to determine the setting of the SIP in Afrikaans are the presence/absence of TECs and the presence/absence of OSCs. Although it has been claimed that Afrikaans allows neither TECs nor OSCs (see, for example, Donaldson 1993; Bobaljik and Jonas 1996; Koeneman 2000), this paper provides arguments, as well as evidence from native speaker judgments, that show that both of these constructions are indeed allowed in Afrikaans. In so doing, the paper provides evidence for a $[+\mathrm{SIP}]$ setting in Afrikaans. The paper is organized as follows: section 2 provides a brief discussion of the SIP; section 3 provides evidence for the existence of TECs in Afrikaans; section 4 provides evidence for the existence of OSCs in Afrikaans; and section 5 provides a brief conclusion. 


\section{The Split-IP parameter}

Section 2.1 introduces Thráinsson's (1996) SIP and Bobaljik and Thráinsson's (henceforth: "BandT") (1998) proposal regarding properties that are linked to the setting of the SIP, section 2.2 briefly discusses the potential impact of recent developments in minimalist syntax on BandT's proposal, and section 2.3 applies BandT's proposal to Afrikaans.

\subsection{Background}

One of the main areas of investigation in generative syntax continues to be the internal structure of the IP-complex, i.e., the question of which functional categories make up what used to be referred to simply as "IP". Following Chomsky's (1991) adaptation of Pollock's (1989) proposal that tense and agreement features are hosted by separate functional categories, it was commonly assumed that all languages have an IP that is "split up" into AgrSP, TP and AgrOP. Contrary to this assumption, Iatridou (1990) suggested that languages might differ as to which functional categories occur in IP and, specifically, that some languages might not have agreement projections. Thráinsson (1996) followed up on this suggestion in proposing the Split-IP parameter (see (1) below), according to which some languages ([-SIP] languages) have a simple, unsplit IP, while other languages ([+SIP] languages) have a more complex, split IP, containing (at least) AgrSP, TP, and AgrOP. ${ }^{2}$

\section{(1) The Split-IP Parameter (SIP)}

Languages that have a positive value for SIP have AgrSP and TP as separate functional projections. Languages with a negative value of SIP are characterized by an unsplit (pre-Pollockian) IP.

Thráinsson (1996: 262)

As mentioned above, BandT (1998) showed how the Split-IP parameter could account for the cross-linguistic clustering of a number of superficially unrelated properties: multiple inflectional morphemes, TECs, OSCs, and verb movement in non-V2 environments. As explained below, these properties are all related to the fact that $[+\mathrm{SIP}]$ languages have (i) more head positions, and (ii) more specifier positions in their IP-complex than do [-SIP] languages. 
Multiple inflectional morphemes involve more than one (overt) inflectional morpheme (specifically, both an agreement marker and a tense marker) occurring on a single verb form (see (3a) below). On the assumption that inflectional morphemes correspond to inflectional heads in the syntax, multiple inflectional morphemes are only allowed in [+SIP] languages, because only [+SIP] languages have the required number of head positions in their IPcomplex (BandT 1998: 58; Bobaljik and Jonas 1996; Thráinsson 1996).

Transitive expletive constructions are constructions that contain both a transitive verb and an expletive (see (3b) below). The assumption here is that the subject NP of a transitive verb is not allowed to remain VP-internal (see, for example, Bobaljik and Jonas 1996; Alexiadou and Anagnostopoulou 1997; Chomsky 1995). ${ }^{3}$ This means that in [-SIP] languages the subject NP of a transitive verb must move into Spec,IP, since there is no other specifier position higher than Spec,VP; but this is exactly the position that an expletive would occupy. Thus, in TECs in [-SIP] languages two elements (the expletive and the subject NP) compete for a single position (Spec,IP). This explains why TECs are ungrammatical in [-SIP] languages: these languages simply do not have the phrase structure to accommodate TECs. In [+SIP] languages, on the other hand, there is more than one specifier position above Spec,VP: if an expletive occupies Spec,AgrSP, the subject can still raise out of Spec,VP and into Spec,TP.

Object shift constructions are constructions in which the direct object NP (necessarily a full NP and not a pronoun) ${ }^{4}$ has been moved leftward across an element that is taken to mark the left edge of VP: a negative element, floating quantifier or sentence medial adverb (for the sake of convenience, these elements will be referred to as "left-edge markers") (see (3c) below). The assumption here is that the landing site of object shift is Spec,AgrOP. In [+SIP] languages the subject occupies Spec,AgrSP and the object can be moved into Spec,AgrOP. In [-SIP] languages, on the other hand, the subject occupies Spec,IP and there is no additional position above VP to which the object can move. In this way, only [+SIP] languages have the phrase structure to accommodate OSCs. ${ }^{5}$

A final property that is linked to the setting of the SIP is the position of the verb in non-V2 environments. ${ }^{6}$ Whether or not the verb has raised out of VP in non-V2 environments can be determined by noticing the position of the verb relative to left-edge markers: if the verb has raised out of VP, then it will precede left-edge markers (see (3d) below); if the verb has not 
raised out of VP, then it will follow left-edge markers (see (2d) below). It follows from BandT's theory of checking that verb raising in non-V2 environments is obligatory in [+SIP] languages and prohibited in [-SIP] languages. The crucial assumptions that BandT (1998: 39) make are that (i) "the features of a projection are those of its head", (ii) "movement occurs solely for the purposes of feature checking", and (iii) "features are checked in all and only local relations to a head" (where the "local relations" are specifier-head, head-complement and head-head). This means that in [-SIP] languages verb raising will not be required in nonV2 environments: if $\mathrm{V}$ and I have features that need to be checked against each other (as is assumed to be the case), then this checking will simply occur between I and VP, since they are in a head-complement (hence, local) relation to each other (see assumption (iii) above) and the features of VP are those of V (see assumption (i) above). Because verb raising is not required for the purposes of feature checking, it is prohibited (see assumption (ii) above). This means that in [-SIP] languages verb raising is prohibited in non-V2 environments. In [+SIP] languages, on the other hand, if $\mathrm{V}$ and AgrS have features that need to be checked against each other (as is assumed to be the case), then this checking cannot occur with the verb in its original VP-internal position, since neither V nor VP is in a local relation with AgrS. For this reason, the verb must raise out of VP and into a position that is in a local relation with AgrS, so that the relevant features of these two heads (V and AgrS) can be checked against each other. This means that in [+SIP] languages verb raising out of VP is obligatory in non-V2 environments. $^{7}$

The consequences of the setting of the SIP are summarized in Table 1 below, and the distribution of the relevant properties in [+SIP] vs. [-SIP] languages is illustrated by the examples from English (a [-SIP] language) and Icelandic (a [+SIP] language) in (2) and (3), respectively.

Table 1. Consequences of the setting of the SIP

\begin{tabular}{|c|c|c|}
\hline & {$[+\mathrm{SIP}]$} & {$[-\mathrm{SIP}]$} \\
\hline multiple inflectional morphemes & possible & impossible \\
\hline transitive expletive constructions (TECs) & possible & impossible \\
\hline full NP object shift constructions (OSCs) & possible & impossible \\
\hline verb raising in non-V2 environments & obligatory & prohibited \\
\hline
\end{tabular}


(2) English [-SIP]

(a) *multiple inflectional morphemes ${ }^{8}$

$3^{\text {rd }}$ person singular form of the verb walk in the past tense:

walk + -ed $+\quad-s=$ *walkeds

verb $\quad+$ past tense marker $\quad+\quad$ agreement marker

Also:

walk + -s + -ed $\quad$ * walksed

verb + agreement marker $\quad+\quad$ past tense marker

(b) *TECs

*There has a cat eaten the mice.

(c) *OSCs

*I did three books not read.

(d) *verb raising in non-V2 environments

Helgi often reads books.

*Helgi reads often books.

(3) Icelandic [+SIP]

(a) $\checkmark$ multiple inflectional morphemes

$2^{\text {nd }}$ person singular form of the verb kasta "throw" in the past tense:

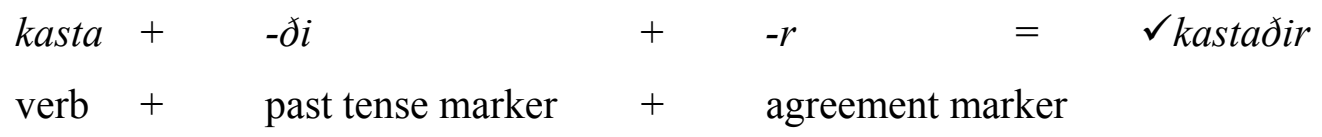

(b) $\checkmark$ TECs

Баð hefur einhver köttur étið mýsnar.

expletive has some cat eaten mice-the

"A cat has eaten mice."

(c) $\checkmark$ OSCs

Ég las prjár boekur ekki.

I read three book-pl not

"I didn't read three books." 
(d) $\checkmark$ verb raising in non-V2 environments

\begin{tabular}{|c|c|c|c|c|}
\hline$\dot{E} g$ & spurði af hverju & Helgi las & $o f t$ & boekur. \\
\hline $\mathrm{I}$ & asked why & Helgi read (past tense) & often & books \\
\hline
\end{tabular}

\subsection{Recent developments in minimalist syntax}

Two relatively recent developments within minimalist syntax which might be expected to negatively affect the validity of BandT's proposal as set out in the previous section are (i) the proposal that AgrSP and AgrOP should be abandoned, and (ii) the proposal for a $v \mathrm{P}$ (light verb projection) above VP.

Hornstein, Nunes and Grohman (2005: 161-169) explain that the proposal for the abandonment of AgrSP and AgrOP (see, for example, Chomsky 1995: chapter 4) is based on the observation that the existence of these two projections is motivated purely by theoryinternal considerations. If one agrees that these two projections should be abandoned, the question arises as to whether a parameter like the SIP is still feasible. Bobaljik (p.c.) notes that the label "Agr" is not a key component of BandT's (1998) analysis, and that within an Agr-less system, something like the SIP can still be maintained: a parameter that divides languages into those with more structure within the IP-complex vs. those with less structure within the IP-complex.

That "AgrP" is merely a convenient label for BandT is apparent from the formulation of their Verb Position Diagnostic (which links verb raising in non-V2 environments to the [+SIP] setting, as explained in the previous section): "If the finite verb raises out of VP in simple non-V2, finite environments, then there must be at least two heads in the IP-complex, the higher of [which - SC], at least, must have features to check with V(P)" (BandT 1998: 43). Here it is notable that no mention is made of specific labels such as "AgrP" or "TP", the reason being that these labels are not significant for BandT's proposal, as summarized in Table 1. For BandT, it is sufficient to note that there are at least two projections in the IPcomplex of $[+\mathrm{SIP}]$ languages, whereas there is only one projection in the IP-complex of [-SIP] languages; the specific features of these projections are irrelevant (BandT 1998: 4143). 
Interestingly, Hornstein et al. (2005: 168) admit that the existence of precisely one of the constructions linked to the SIP, namely, transitive expletive constructions, is problematic for an Agr-less system and might force a return to the Pollockian (Agr-containing) system:

the line of reasoning pursued [in the proposed abandonment of the AgrPs - SC] is not simply against the postulation of extra functional categories, but rather against categories that can't be motivated in terms of the interface levels. It could be the case, for instance, that [AgrS - SC] is indeed visible at LF, but it so happens that our theoretical tools are not yet sharp enough to detect its effects at LF. And, of course, it could also be the case that [a TEC - SC] really represents a departure from optimality and that we are forced to postulate an Agr-projection. As stressed in previous chapters, even the second result would be interesting. It would have shown that even if we started from different assumptions, we would be bound to reach a Pollockian system, with some Agr-projections that are not motivated in terms of the interface levels. The world would definitely not end with such a conclusion.

Hornstein et al. (2005: 168)

The second development that is potentially relevant to BandT's theory - the proposal for a light verb projection - is a consequence of the minimalist endeavour to get rid of the notion of government. Abandoning this notion involved a reinterpretation of the Predicate-Internal Subject Hypothesis (PISH) ${ }^{9}$ in terms of verbal shells; specifically, the proposal for a light verb projection $(v \mathrm{P})$ above VP. Whereas VP is headed by the (overt) contentful verb, $v \mathrm{P}$ is headed by a phonetically null light verb "whose meaning is heavily dependent on the meaning of its complement" (Hornstein et al. 2005: 98). The idea is that internal arguments are generated within VP, while the external argument of ditransitive, simple transitive, and unergative constructions is generated in the specifier position of $v \mathrm{P}$ (Hornstein et al. 2005: 110). ${ }^{10}$ The question that arises is whether the existence of a $v \mathrm{P}$ between VP and the IPcomplex is problematic for BandT's theory of verb movement.

Recall that BandT claim that in [-SIP] languages, the verb can check its features against those of the inflectional head in situ given that (i) the features of VP are those of V, and (ii) VP is in a local relation with the inflectional head (see BandT's assumptions regarding feature checking - section 2.1). But if there is a $v$ P between VP and IP, then VP is no longer in a local 
relation with the inflectional head, even in [-SIP] languages. Would this not force movement of the verb into the IP-complex even in [-SIP] languages, contrary to the prediction made by BandT's Verb Position Diagnostic (see above)? The answer is "no", because the claim is that the content verb always moves into $v \mathrm{P}$ and this means that, even in the $v \mathrm{P}$-framework, no functional head intervenes between the projection that hosts the content verb $(v \mathrm{P})$ and the inflectional head with which the verb needs to check features. It should be clear from this discussion that the internal structure of the "VP-complex" is irrelevant to BandT's theory as long as the relation between the projection hosting the content verb, and the inflectional head does not change.

The aim of this section was to show that neither the abandonment of AgrP nor the existence of a $v \mathrm{P}$ is problematic for BandT's proposal, as summarized in Table 1. The focus in this section was on non-V2 verb movement, since the Verb Position Diagnostic is central to BandT's proposal. However, it should be noted that, just like non-V2 verb movement, none of the other properties mentioned in Table 1 is affected by the minimalist developments discussed here. Regardless of (i) what the labels are that are used for the inflectional head(s) in the IP-complex, and (ii) what the internal structure of the "VP-complex" is, the fact remains that $[+\mathrm{SIP}]$ languages have additional projections (and, therefore, additional specifier and head positions) in their IP-complex that do not exist in [-SIP] languages, which, in turn, means that only $[+$ SIP] languages have the phrase structure to accommodate constructions that make use of these additional projections, such as multiple inflectional morphemes, TECs and OSCs.

\subsection{Afrikaans}

According to the diagnostics in Table 1, English, Swedish, Danish and Norwegian are classified as [-SIP] languages, while Icelandic, Dutch and German are classified as [+SIP] languages. Because of the close relationship between Afrikaans and Dutch (and, to a lesser extent, German), one might expect Afrikaans to be a [+SIP] language, as well. Unfortunately, two of the diagnostics used to determine the setting of the SIP in a language - (i) the position of the verb in non-V2 environments, and (ii) the (im)possibility of multiple inflectional morphemes - are of no use in the case of Afrikaans, as is explained directly below. 
Afrikaans is an SOV V2 language that closely resembles Dutch and German in that the finite verb appears in second position in subject-initial main clauses (see (4a)) and non-subjectinitial main clauses (see (4b)), and in final position in embedded clauses (see (4c)). Like German and Dutch, Afrikaans is, therefore, assumed to have a head-final VP, head-final TP, and head-initial CP (with features that require that the verb raise into $\mathrm{C}$ and an XP raise into Spec, CP). ${ }^{11}$
(a) Sara eet vrugte.
Sarah eat fruit
"Sarah eats fruit."
(b) Vandag eet Sara vrugte. today eat Sara fruit
"Today Sara eats fruit."
(c) wy weet dat Sara vrugte eet.
he knows that Sara fruit eat
"He knows that Sarah eats fruit."

As can be seen in (5) below, the finite verb precedes the negative element nie (see (5a)), floating quantifiers (see (5b)), and sentence-medial adverbs (see (5c)) in Afrikaans subjectinitial main clauses.
(a) Sy eet nie vrugte nie.
she eats not fruit final-neg
"She does not eat fruit."
* Sy nie eet vrugte nie.
(b) Die kinders weet almal wie hy is.
the children know all who he is
"The children all know who he is."
*Die kinders almal weet wie hy is.
(c) Hulle verloor selde 'n wedstryd.

they lose seldom a game
"They seldom lose a game."
*Hulle selde verloor ' $n$ wedstryd. 
At first sight, the data in (5) might seem to provide evidence for a [+SIP] setting in Afrikaans, given that the verb clearly raises out of VP in these constructions, as evidenced by the fact that it precedes the left-edge marker in each case. However, BandT assume that subject-initial main clauses (such as those in (5)) are CPs. This means that in Afrikaans, subject-initial main clauses are V2 environments, which, in turn, means that the position of the verb relative to left-edge markers in these constructions is indicative of the setting of the V2 parameter and does not provide any evidence for the setting of the SIP in this language. Embedded clauses (such as that in $(4 \mathrm{c})$ ) are non-V2 environments in Afrikaans and, in theory, the position of the finite verb in these clauses should thus indicate the setting of the SIP (finite verb inside VP in embedded clauses $=[-$ SIP $]$ vs. finite verb raised out of VP in embedded clauses $=[+\mathrm{SIP}])$. However, recall that Afrikaans has a head-final VP and a head-final TP. Thus, movement from $\mathrm{V}$ to $\mathrm{T}$ is string-vacuous and, for this reason, it is impossible to determine whether the finite verb is in $\mathrm{V}$ or in $\mathrm{T}$ in Afrikaans embedded clauses. ${ }^{12}$ In this way, it is impossible to determine whether or not Afrikaans has verb raising in non-V2 environments and, consequently, this diagnostic is of no use in determining the setting of the SIP in this language.

The other SIP-diagnostic that is of no use in the case of Afrikaans is the question as to whether or not the language allows multiple inflectional morphemes. In Afrikaans, past tense on lexical verbs is indicated by the auxiliary het "have" and the past participial form of the verb (prefix ge-plus stem). In the case of modals and the copula wees "to be", past tense is indicated by a stem change. ${ }^{13}$ This is illustrated by the sentences in (6) to (8).
(a) Ek werk vandag.
I work today
"I am working today."
(b) Ek het gister gewerk.
I have yesterday worked
"I worked yesterday."

(7) (a) Hulle moet na jou luister.

they must to you listen

"They have to listen to you." 
(b) Hulle moes na die hele toespraak luister. they must to the whole speech listen

"They had to listen to the whole speech."

(8)
(a) Ek is bly dat jy hier is.
I am glad that you here are
"I am glad that you are here."
(b) wk bly dat jy daar was.
I was glad that you there were
"I was glad that you were there."

Regardless of whether one considers Afrikaans to have overt tense markers on the basis of the above-mentioned data, it is clear that this language does not have any overt agreement markers. This is illustrated by the "agreement" paradigms of the present and past tense forms of the verb werk "work" in (9), the modal kan "can" in (10), and the copula wees "to be" in (11).

(9) Present
$e k$ ("I") werk
ons ("we") werk
jy ("you (sg)") werk
julle ("you (pl)") werk
hy / sy / dit ("he / she / it") werk
hulle ("they") werk

\section{Past}

ek het gewerk

ons het gewerk

jy het gewerk

julle het gewerk

hy / sy / dit het gewerk

hulle het gewerk

\section{(10) Present}
ek kan
ons kan
jy kan
julle kan
hy / sy / dit kan
hulle kan 
Past

ek kon

jy kon

hy / sy / dit kon ons kon

julle kon

hulle kon

ons is

julle is

hulle is

ons was

julle was

hulle was

On the basis of the past tense forms in (9) to (11), one might be tempted to conclude that because Afrikaans does not exhibit multiple inflectional morphemes, it must be a [-SIP] language. However, one can only conclude that a language is [-SIP] on the basis of this diagnostic if (i) the language has overt tense markers and overt agreement markers, and (ii) these cannot occur on the same verb form. Since Afrikaans does not have overt agreement markers, the question of whether or not this language allows multiple inflectional morphemes, i.e., both an agreement marker and a tense marker, on a single verb form is a non-question. In this way, the (im)possibility of multiple inflectional morphemes, just like the (im)possibility of verb raising in non-V2 environments, cannot be used to determine the setting of the SIP in Afrikaans.

This means that the only two diagnostics that can be used to determine the setting of the SIP in Afrikaans are (i) the (im)possibility of TECs, and (ii) the (im)possibility of OSCs. In the following two sections, I will argue that Afrikaans does indeed allow both TECs and OSCs and that, therefore, Afrikaans must be [+SIP]. On this topic, a final note is in order with respect to Table 1 . The only property mentioned in this table that involves a necessity and not simply a potentiality is the verb raising property: verb raising is obligatory in [+SIP] languages and prohibited in [-SIP] languages. All three of the other properties refer to potentialities: if a language has a split IP, it has the potential for multiple inflectional 
morphemes, TECs and OSCs. However, this does not mean that every [+SIP] language will necessarily exhibit all of these properties, since a number of other factors are relevant. For example, if a language has a split IP but it does not have (the right kind of) expletives, it will not have TECs; and if a language has a split IP but it does not have overt tense and agreement markers (as is the case in Afrikaans), then the potential for multiple inflectional morphemes will not be realized (or, probably more accurately, this potential will simply not be visible). However, regardless of any other factors, [-SIP] languages cannot allow any of these properties (multiple inflectional morphemes, TECs or OSCs), since these languages simply do not have the phrase structure to accommodate these properties. Therefore, if it can be shown that Afrikaans allows TECs and/or OSCs, then it follows that Afrikaans must be a [+SIP] language, regardless of the fact that the other two SIP-diagnostics are of no use. Let us now turn to the relevant Afrikaans data.

\section{Evidence for transitive expletive constructions in Afrikaans}

Bobaljik and Jonas (1996: 208) follow Donaldson (1993) in claiming that Afrikaans does not allow TECs. However, the results of Conradie $(2005,2006)$ provide evidence that Afrikaans does indeed allow TECs. Conradie conducted studies on the second language acquisition of Afrikaans, focusing on properties linked to the SIP, including TECs. An Afrikaans native speaker group was included in both studies to act as a control group. Participants completed three tasks - a grammaticality judgment task, a sentence manipulation task, and a truth-value judgment task - but only the grammaticality judgment task is of interest here. This task is based on the written preference task in White (1991). Participants were presented with 50 pairs of sentences and asked to circle one of the options below each pair. One of the 10 TECpairs in this task is given in (12) below.

(a) Drie vrouens het koek verkoop by die fees.
three women have cake sold at the festival
"Three women sold cake at the festival."
(b) Daar het drie vrouens koek verkoop by die fees.
there have three women cake sold at the festival
"Three women sold cake at the festival."

Only (a) is possible Only (b) is possible Both possible Both impossible Don't know 
(12a) and (12b) are identical in meaning but (12a) is a non-TEC and (12b) its TEC-equivalent. All of the TEC-pairs in the task were made up of such a non-TEC and its TEC-equivalent. In some pairs, the TEC was the (a)-sentence and in others it was the (b)-sentence. If TECs are prohibited in Afrikaans, as Donaldson claims, then native speakers of Afrikaans should choose "only (a) is possible" or "only (b) is possible" for the TEC-pairs in this task, depending on which sentence is the non-TEC in the specific pair; for example, they should choose "only (a) is possible" for the pair in (12). However, if TECs are allowed in Afrikaans, then native speakers should choose "both possible" for each of the pairs, accepting both the non-TEC and its TEC-counterpart. Two different groups of Afrikaans native speakers were included in the two second language studies conducted by Conradie, to act as control groups for the second language learners' results: $n=20$ in Conradie (2005) and $n=10$ in Conradie (2006). The "both possible" option was chosen by the Afrikaans native speakers for the TEC-pairs on the grammaticality judgment task in $93 \%$ of the cases in Conradie (2005) and in $90 \%$ of the cases in Conradie (2006). This provides evidence that constructions such as that in (12b) are indeed allowed in Afrikaans.

However, Donaldson claims that constructions such as that in (12b) are not really TECs. He claims that, in constructions that look like TECs in Afrikaans, daar "there" must be interpreted as a locative and cannot be interpreted as an expletive. I will argue that this is not the case and that Afrikaans does indeed allow true TECs. Firstly, consider the sentences in (13) to (15).

Daar het iemand daar vuur gemaak. there has someone there fire made

"Someone made a fire there."

(14) Gister daar iemand daar ' $n$ vuur gemaak. yesterday has there someone there a fire made

"Yesterday someone made a fire there."

(15) A: Daar het 'n agent vir Jan gebel oor sy huis. there has an agent for Jan phonedabout his house "An agent phoned Jan about his house." 


\section{B: \#Regtig? Waar? \\ "Really? Where?"}

If both instances of daar were to be interpreted as locatives in each of the sentences in (13) and (14), the sentences would be ill-formed because of the occurrence of two identical locative adverbs in the same sentence (in the same way that There I made a fire there is illformed in English). Since the sentences are not ill-formed, this entails that, in each of these sentences, one of the instances of daar must be an expletive; hence, these are TECs. In (15), there is only one specific context in which B's question would be felicitous in response to A's statement: if A and B have been talking about Jan having traveled to some specific location, then daar can refer to this specific location so that A might reply "The agent phoned him (Jan) in London / while he was in London". In this context, daar in A's utterance would be emphasized. In any other context, where there has been no mention of Jan traveling somewhere (also, for example, at the beginning of a conversation), daar would not be emphasized and B's question would be infelicitous although A's utterance would remain grammatical. Because there are certain contexts in which B's question is infelicitous, this means that there are certain contexts in which daar in A's utterance cannot be interpreted as a locative and must be interpreted as an expletive. In these contexts, A's utterance is another instance of a true TEC.

Secondly, note that locative daar and expletive daar seem to differ in their distribution. The sentences in (16) below show that in Afrikaans the preference is for a locative adverbial phrase (here, op die strand "on the beach") to occur between the subject (here, iemand "someone") and the object (here, 'n vuur "a fire"), rather than in the position preceding both the subject and the object. ${ }^{14}$ Some native speakers consider (16b) ungrammatical, and those who consider it grammatical still prefer (16a).

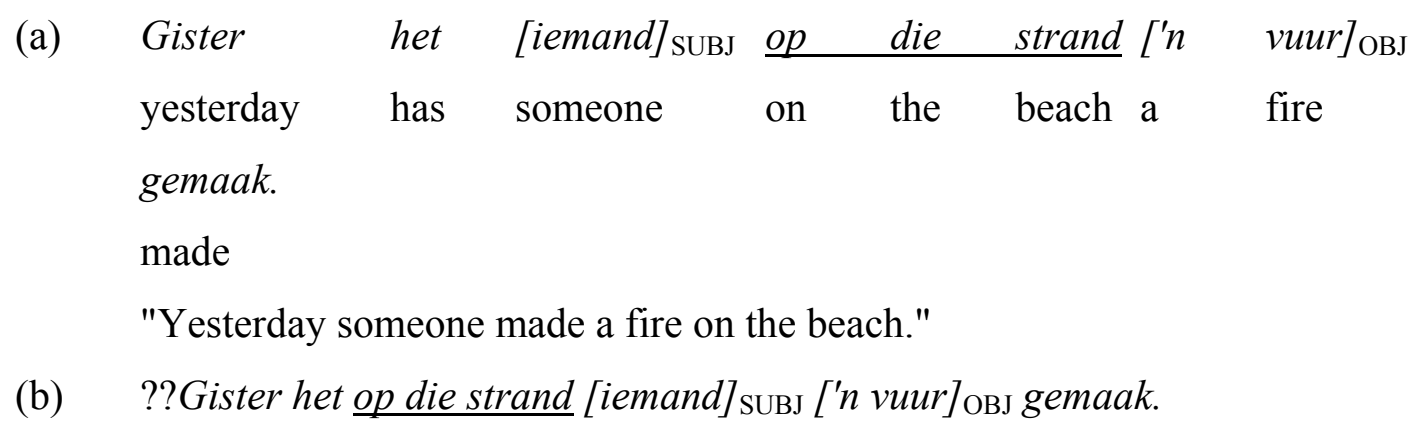


In (17) below, daar is placed between the subject and the object - the preferred position for locatives (cf. (16a)) - and the sentence can only mean "Yesterday someone made a fire there"; i.e., daar has to be interpreted as a locative. In (18) daar precedes both the subject and the object and it is possible to interpret it as a locative - in which case the sentence means "Yesterday someone made a fire there" - although this involves a marked construction (cf. (16b)). More importantly, though, (18) can also mean "Yesterday someone made a fire", without any locative adverb. In fact, this is the only meaning that comes to mind when daar is not emphasized. For (18) to mean "Yesterday someone made a fire", i.e., excluding the locative adverb, daar has to be interpreted as an expletive, which means that, on this reading, (18) involves a true TEC.

\begin{tabular}{|c|c|c|c|c|c|}
\hline Gister & het & {$[\text { iemand }]_{\text {SUBJ }}$} & daar $\quad[' n$ & vuur $]_{\mathrm{OBJ}}$ & gemaak \\
\hline yesterday & has & someone & there $a$ & fire & made \\
\hline
\end{tabular}

\begin{tabular}{|c|c|c|c|c|c|}
\hline Gister & het & daar & {$[\text { iemand] }]_{\text {SUBJ }}$} & {$[' n$} & vuur $]_{\mathrm{OBJ}}$ \\
\hline yesterday & has & there & someone & $\mathrm{a}$ & fire \\
\hline
\end{tabular}

"Yesterday someone made a fire."

The claim that (non-emphasized) daar must be an expletive in (18) receives additional support from the fact that this daar cannot be interpreted as a locative even if it is focused by adding a phrase such as nie hier nie "not here". This phrase can, however, be added to the sentence in (17) to focus the locative daar. This is illustrated by the sentences in (19).
(a) Gister het iemand daar (locative) 'n vuur gemaak (=(17)), nie hier nie.
"Yesterday someone made a fire there, not here."
(b) ??Gister het daar (expletive) iemand 'n vuur gemaak (=(18)), nie hier nie.

Given the data in (13) to (19), it should be clear that Afrikaans does indeed allow true TECs.

Before turning to the evidence for OSCs in Afrikaans, I will briefly consider Koeneman's (2000) prediction that TECs should not occur in languages such as Dutch and Afrikaans and his argument that constructions that look like TECs in these languages actually involve what he calls "expletive adverbs", rather than "expletive subjects". 
Koeneman's aim is to formulate triggers for verb movement that can account for crosslinguistic differences in verb placement. Whereas BandT assume that the verb moves in order to check some feature, Koeneman proposes that the verb moves in order to project some feature (that corresponds to a morphological property of the verb) so that this feature may occupy a certain structural position in relation to other elements. The verb enters the derivation fully inflected with its tense affix introducing tense features and its agreement affix introducing agreement features (Koeneman 2000: 5, 6). He defines V-to-I movement (= nonV2 verb movement) and V-to-C movement (= V2 movement) as in (20) below.

(20) (a) V to I movement is an operation that the verb undertakes in order to put rich agreement features in the predicational domain of VP.

(b) $\mathrm{V}$ to $\mathrm{C}$ movement is an operation that the verb undertakes in order to put tense features in a position where they take scope over the subject and the predicate.

(Koeneman 2000: 47)

In short, V-to-I movement is triggered by the need to project rich agreement features (in the form of AgrP), whereas $\mathrm{V}$-to-C movement is triggered by the need to project tense features (in the form of TP). The question then arises as to how Koeneman defines rich morphology. BandT define "rich" morphology structurally, as the potential to have multiple inflectional morphemes; specifically, both an agreement marker and a tense marker on a single verb form, given multiple inflectional heads. In Koeneman's theory of verb movement, on the other hand, the richness of a language's morphology is determined by the number of distinctions present in its morphological paradigm (Koeneman 2000: 62, 72; see also Rohrbacher 1994, 1999; Vikner 1995, 1997). This is referred to as a paradigmatic view of morphological richness.

Another difference between the two theories of verb movement concerns the relationship between rich morphology and non-V2 verb movement. Under BandT's theory, there is no direct relationship between "rich" morphology (= multiple inflectional morphemes) and nonV2 verb movement. Both the potential for multiple inflectional morphemes and the requirement for non-V2 verb movement are independently linked to the phrase structure of a language: if a language has a split IP, then (i) it has the potential for multiple inflectional morphemes, and (ii) it requires verb movement in non-V2 environments; if a language has an unsplit IP, on the other hand, then (i) it does not allow multiple inflectional morphemes, and 
(ii) it prohibits verb movement in non-V2 environments. The SIP is a syntactic parameter with syntactic and morphological consequences; in other words, the syntax determines the morphology. This is referred to as a Late Insertion theory. Koeneman, on the other hand, follows researchers such as Rohrbacher $(1994,1999)$ and Vikner $(1995,1997)$ in claiming that there is a direct triggering relationship between rich morphology and V-to-I movement. In this way, Koeneman's theory represents a morphology-driven approach: certain morphological affixes on the verb trigger syntactic movement of the verb.

It has already been explained (see note 8 regarding English, and section 2.3 regarding Afrikaans) that, under BandT's theory, if a language is [+SIP], then it has the potential for multiple inflectional morphemes but that some [+SIP] languages cannot visibly exploit this potential because they do not have overt tense and agreement morphemes. This means that there is a one-way implication between multiple inflectional morphemes and the [+SIP] setting: if a language exhibits multiple inflectional morphemes, then it must be [+SIP], but if a language is $[+\mathrm{SIP}]$, it will not necessarily exhibit multiple inflectional morphemes. In this way, BandT's theory allows for languages that lack "rich" morphology but are clearly [+SIP] in that they have the relevant syntactic properties. In this paper it is argued that Afrikaans is one such a language. Koeneman (2000: 58) agrees that the implication between "rich" morphology and non-V2 verb movement is a one-way implication, noting that there are languages that have V-to-I movement in the absence of rich morphology, such as the Tromsø dialect of Norwegian and the dialect of Swedish spoken in Kronoby (Finland). However, he also states that "the verb movement parameter has two values, on or off. The value is determined on the basis of the top node of the agreement paradigm: It is only [my emphasis $\mathrm{SC}$ ] switched on when the feature matrix underlying all finite verb forms contains three features [i.e., in the presence of rich morphology - SC]" (Koeneman 2000: 79). Statements such as these seem to incorporate the assumption that there is indeed a two-way implication. Under Koeneman's theory, languages that have V-to-I movement in the absence of "rich" morphology must thus be treated as exceptions. They can be accommodated within his theory but only by means of additional stipulations: in languages with V-to-I movement and rich morphology, rich morphology triggers verb movement; ${ }^{15}$ in languages with V-to-I movement but without rich morphology, there is a different trigger for verb movement. Furthermore, Koeneman (p.c.) notes that such V-to-I movement in the absence of rich morphology is 
assumed to differ from the V-to-I movement that is triggered by rich morphology in that the former does not project AgrP.

Koeneman (2000: 181-182) notes that Afrikaans is a V2 language because the verb appears in second position in non-subject-initial main clauses (see (4b) above), ${ }^{16}$ and that Afrikaans, therefore, projects TP. For BandT, the fact that Afrikaans lacks overt agreement morphology (see (9) to (11) above) means that morphology provides no indication as to the presence/absence of V-to-I movement. In Koeneman's analysis of Afrikaans, the fact that this language is poorly inflected is regarded as an indication that it does not have V-to-I movement, i.e., does not project AgrP (Koeneman 2000: 182). ${ }^{17}$ Given Koeneman's assumption that a language must project both AgrP and TP in order to generate TECs, his theory predicts that Afrikaans should not allow TECs (Koeneman 2000: 164, 183). This means that the Afrikaans data presented in this section are problematic for Koeneman in the same way as the corresponding Dutch data are. Koeneman argues that because Dutch is a V2 language, is poorly inflected, and allows PP-extraposition (as does Afrikaans), this language projects TP but not AgrP. This means that Dutch should not allow TECs. Koeneman (2000: 189-193) then argues that the constructions that look like TECs in this language are not really TECs since the "expletives" in these constructions should actually be analyzed as "semilocative/expletive adverbs". Expletive adverbs are expletive in that they do not have lexical meaning but they differ from expletive subjects in a number of ways. The question is now whether the same could be argued for Afrikaans: are the "expletives" in Afrikaans constructions that look like TECs actually expletive adverbs instead of expletive subjects?

Koeneman argues that because expletives can occur in third position in Dutch TECs something which is not possible in Icelandic, Yiddish or German TECs - they must be analyzed as expletive adverbs, with the following two properties: unlike real expletive subjects (i) they affect both the subject and the object, in that the object may not refer to entities mentioned earlier in the discourse (i.e., the object may not express old information), and (ii) they can co-occur with real expletives. Koeneman (2000: 191-192) shows how both of these properties hold for the pseudo-expletives in Dutch TECs. His examples are given in (21) and (22) below. 


(21) \#Er heeft niemand 'm de laaste tijd gezien.
there has no-one him the last time seen
"No-one has seen him recently."
(22) Er heeft er iemand een appel gegeten.
there has there someone an apple eaten
"Someone ate an apple."

In response to the question "How are things with your friend?", (21) is ungrammatical because the object ' $m$ "him" expresses old information (in that it refers to the speaker's friend, who has already been mentioned in the discourse) and, therefore, cannot occur together with the pseudo-expletive / expletive adverb er. In (22), both instances of er can be interpreted as non-locative (as indicated by the meaning of the sentence), and although one instance of er can be regarded as a real expletive, the other must be a pseudo-expletive / expletive adverb. Afrikaans is like Dutch in allowing expletives to occur in third position (see (23) below).

Gister het daar iemand 'n appel geëet.
yesteday has there someone an apple eaten.
"Yesterday someone ate an apple."

However, the expletives in Afrikaans TECs do not have the two properties mentioned above as diagnostics for expletive adverbs. Firstly, these expletives only affect the subject and not the object. This is illustrated by the example in (24) below which shows that an expletive can occur together with an object that expresses old information.

$\begin{array}{lllllll}\text { (24) A: } & \text { Het } & \text { niemand vir Jan gekontak } & \text { oor sy huis nie? } \\ & \text { has nobody for Jan contacted } & \text { about his house final-neg }\end{array}$ "Has nobody contacted Jan about his house?"

$\begin{array}{llllll}\text { B: Daar het } & \text { 'n eiendomsagent } & \text { hom gekontak daaroor. } \\ & \text { there has an } & \text { estate.agent } & \text { him contacted there.about }\end{array}$

"An estate agent did contact him (= Jan = old information) about it." 
Secondly, Afrikaans non-locative daar cannot co-occur with a "real" expletive. This is illustrated by the sentences in (25) and (26) below. (25) can mean either "Someone ate an apple" or "Someone ate an apple there", which means that in (25) the single instance of daar can be interpreted either as an expletive or as a true locative. However, (26) only has one meaning: "Someone ate an apple there", which means that in (26) one of the instances of daar has to be interpreted as a locative.

$\begin{array}{llll}\text { Daar het iemand } & \text { appel geëet. } \\ \text { there has someone an apple eaten }\end{array}$

"Someone ate an apple." (if daar = expletive) or

"Someone ate an apple there." (if daar = locative)

(26) Daar het daar iemand 'n appel geëet.
there has there someone an apple eaten

"Someone ate an apple there."

Given the data in (21) to (26), it should be clear that although Afrikaans TECs are problematic for Koeneman's theory in the same way as Dutch TECs are, his argument that Dutch does not have real TECs does not hold for Afrikaans, and I maintain that the data presented in this section provide evidence for the existence of true TECs in this language.

\section{Evidence for object shift constructions in Afrikaans}

The sentences in (27) below show that Afrikaans allows movement of the direct object to a position preceding a left-edge marker. (27a) is a non-OSC and (27b) its OSC-equivalent (in which the direct object NP daardie man has been moved leftward across the negative element nie).
(a) Ek het nie daardie man geken nie.
I have not that man known final-neg
$\begin{array}{lllll}\text { (b) } & \text { het daardie } & \text { man nie } & \text { geken nie. } \\ \text { I } & \text { have that } & \text { man not known final-neg }\end{array}$

"I did not know that man." 


\section{Simone Conradie}

The native speaker judgments obtained in Conradie $(2005,2006)$ confirm that OSCs such as that in (27b) are grammatical in Afrikaans. The grammaticality judgment task mentioned in section 3 above included 15 items which involved object shift (with different left-edge markers: $5 \times$ negative element, $5 \times$ floating quantifier and $5 \times$ sentence-medial adverb). Each of the 15 items involved pairs such as that in (27): a non-OSC and its OSC-equivalent. In some pairs, the OSC was the (a)-sentence and in others it was the (b)-sentence. If OSCs are allowed in Afrikaans, then native speakers should choose "both possible" for each of the pairs, accepting both the non-OSC and its OSC-counterpart. The "both possible" option was chosen by the Afrikaans native speakers for the OSC-pairs on the grammaticality judgment task in $95 \%$ of the cases in Conradie (2005) (recall $n=20$ ), and in $94 \%$ of the cases in Conradie (2006) (recall $n=10)$. This provides evidence that constructions such as that in $(27 b)$ are indeed allowed in Afrikaans.

There is, however, some debate as to whether languages such as Dutch and German (and, therefore, also Afrikaans) have OS, or whether the constructions that look like OS in these languages (such as (27b) above) are, instead, instances of Scrambling, where "OS" is defined as the A-movement of the direct object-NP into Spec,AgrOP, and "Scrambling" is defined as the $\mathrm{A}^{\prime}$-movement of the direct object-NP to an adjoined position (such as the position adjoined to IP). ${ }^{18}$ If Afrikaans object movement constructions are instances of OS, then they provide evidence for a [+SIP] setting in this language (as explained in section 2.1). If, on the other hand, these constructions are instances of Scrambling, then they are irrelevant to the setting of the SIP in this language. To show that Afrikaans has "true" OS (i.e., object movement that requires a split IP), I will consider some diagnostics that have been proposed (by Diesing 1997 and Bobaljik 1995) to distinguish between OS and Scrambling.

Diesing (1997) compared the "reordering possibilities" of Yiddish to those of some West Germanic and Scandinavian languages and concluded that object movement constructions in Yiddish and German are instances of Scrambling, whereas object movement constructions in Dutch and Icelandic are instances of OS. Her conclusion was based primarily on the following differences between object movement constructions in these languages: (i) the direct object cannot move over the subject in Dutch and Icelandic, ${ }^{19}$ but it may do so in German and Yiddish, and (ii) the direct object cannot move over the indirect object in double-object constructions in Dutch and Icelandic, but it may do so in German and Yiddish. The reader is 
referred to Diesing's (1997) paper for an account of the relevance of these two properties. Suffice to say that they are linked to Rizzi's (1990) notion of Relativized Minimality and that, whereas the possibility of the properties mentioned in (i) and (ii) (as in the case of German and Yiddish) indicates that the leftward movement of the direct object is an $\mathrm{A}^{\prime}$-movement (hence, Scrambling), the impossibility of these properties (as in the case of Dutch and Icelandic) indicates that the leftward movement of the direct object is an A-movement (hence, OS). Turning to Afrikaans, the examples in (28) show that this language patterns like Dutch and Icelandic with respect to the property in (i) above, i.e., in not allowing the object to move over the subject. ${ }^{20}$
(a) Gister
het Jan die
boeke nie
gelees nie.
yesterday has
John the
books not
read final-neg
"Yesterday John did not read the books."
(b) *Gister het die boeke Jan nie gelees nie.
yesterday has the books John not read final-neg

With respect to the property in (ii) above, consider the sentences in (29) below.
(a) Ek het nie [vir Marie][die boeke] gegee nie.
I have not for Mary the books given final-neg

"I did not give Mary the books."
(b) Ek het [die boeke] nie [vir Marie]gegee nie.
I have the books not for Mary given final-neg
(c) Ek het nie [die boeke] [vir Marie]gegee nie.
I have not the books for Mary given final-neg
(d) Ek gee altyd [vir Marie] [die boeke].
I give always for Mary the books

"I always give Mary the books."

(e) $k k$ gee altyd [die boeke] [vir Marie].
I give always the books for Mary

"I always give the books to Mary." 
If one compares only (29a) and (29b), one might be tempted to conclude that Afrikaans patterns like German and Yiddish in allowing the direct object (DO) to move over the indirect object (IO) in double object constructions. However, this conclusion rests on the assumption that the underlying order of the objects in (29b) is that in (29a), namely the so-called "base order" IO+DO. However, Afrikaans allows the two objects to occur in either order (IO+DO or DO+IO) below a left-edge marker - compare (29a) to (29c), and (29d) to (29e). Note that both of these orders are grammatical and that neither is marked; the order of the two objects seems to be optional in Afrikaans (although it might lead to very subtle differences in emphasis, comparable to those found between the two orders allowed in English double object constructions - see the translations of (29d) and (29e)). Therefore, I would like to propose that (29b) is derived from (29c), and not from (29a), and that this accounts for the fact that (29b) is grammatical in Afrikaans: the order in the VP was DO+IO to begin with; therefore, when the DO moved out of VP to form (29b), it did not cross the IO, and, for this reason, did not cause a violation of Relativized Minimality.

In fact, there is a class of verbs in Icelandic that patterns like Afrikaans verbs do in allowing the so-called "inversion order" of double objects, namely DO+IO. Some Icelandic verbs (those that Diesing would use to diagnose OS versus Scrambling) allow only the base order IO+DO and do not allow the DO to move out of VP because it would have to move over the IO, causing a violation of Relativized Minimality (see (30a)). ${ }^{21}$ However, some verbs allow the inversion order $\mathrm{DO}+\mathrm{IO}$ (see (30b)) and it is exactly this class of verbs that also allows the DO to move out of the VP to a position preceding the left-edge marker and the IO (see (30c)), something which does not cause a violation of Relativized Minimality because the DO does not move over the IO (since it precedes the IO to begin with) (see Anagnostopoulou 2003). ${ }^{22}$

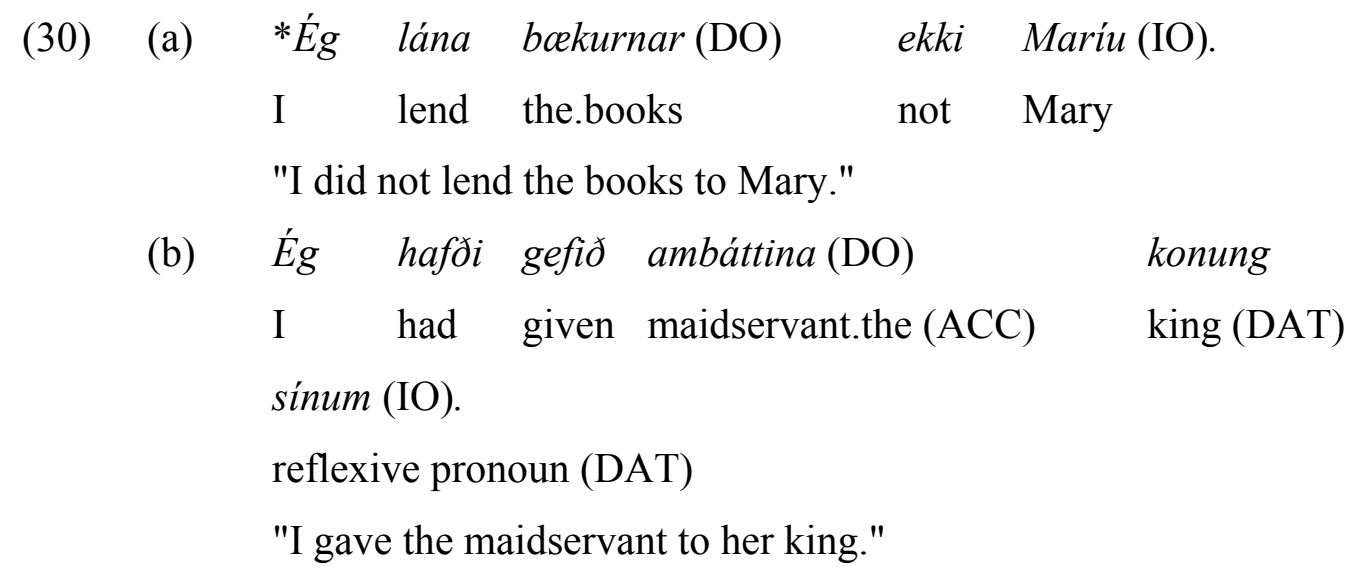




$\begin{array}{llllll}\text { (c) } & \begin{array}{l}\text { Eg } \\ \text { I }\end{array} \text { gave } & \text { ambáttina (DO) } & \text { ekki } & \text { ti } & \text { konunginum (IO). } \\ \text { "I did not give the maidservant to the king." } & & \text { king (DAT) }\end{array}$

The question then arises why Afrikaans should differ from the other four languages in that all of its verbs allow both orderings of the objects. Thráinsson (2001: 198, note 10) mentions that some studies (referred to in Czepluch 1990) "argue for 'alternative projections from one lexical structure', i.e., different underlying orders of objects for different verbs in German also verbs where two orders are equally unmarked". It is thus conceivable that in Afrikaans, all verbs are of this latter type, allowing both object orders at the level of the underlying representation, so that surface IO+DO is most straightforwardly linked to underlying IO+DO, whereas surface DO+IO is most straightforwardly linked to underlying DO+IO.

To summarize, like Dutch and Icelandic, and unlike German and Yiddish, Afrikaans does not allow the object to move over the subject, which provides evidence that object movement constructions in this language are instances of OS (i.e., movement of the direct object to an Aposition) because they show Relativized Minimality effects. If this is true, then it is unexpected that Afrikaans allows double object constructions in which the DO has been moved out of VP without the IO, since this is taken to involve movement of the DO over the IO, which should, in turn, involve a violation of Relativized Minimality. However, the fact that this construction is grammatical is only unexpected under the assumption that all Afrikaans double object constructions have the underlying base order $\mathrm{IO}+\mathrm{DO}$, an assumption that was shown to be untenable in Afrikaans. Afrikaans object movement thus seems to involve A-movement OS rather than A'-movement Scrambling if one employs Diesing's (1997) diagnostics.

Bobaljik (1995: 123-143) also provides arguments for the claim that the leftward movement of the direct object across left-edge markers in Afrikaans involves "A-movement, i.e., shift to Spec,AgrOP, as opposed to clause-internal adjunction or $\mathrm{A}^{\prime}$-movement". His strongest argument involves floating quantifiers. The assumption is that A-movement licenses floating quantifiers while $\mathrm{A}^{\prime}$-movement does not. ${ }^{23}$ It follows that since the object movement operations in Icelandic, German, Dutch and Afrikaans (see (31) below) license floating quantifiers, they must all be instances of A-movement (Bobaljik 1995: 128-135). ${ }^{24}$ 


(a) Hy die boeke sonder twyfel nie almal lees
he will the books without doubt not all read
nie.
final-neg
"He undoubtedly will not read all the books."
Marie het die dronk taalkundiges almal uitgelag.
Marie has the drunk linguists all out.laughed
"Mary laughed at all the drunk linguists."

Consequently, even if one wants to distinguish between A-movement OS, on the one hand, and A'-movement Scrambling, on the other hand, it is safe to conclude that Afrikaans object movement involves "true" OS and, therefore, that object movement constructions in this language provide evidence for a $[+\mathrm{SIP}]$ setting.

In Corver and Van Riemsdijk's (1994) volume on the phenomenon of variable word order within a clause, the question of which type of movement is involved in the case of object movement receives considerable attention. In the introduction to this volume, Corver and Van Riemsdijk (1994: 1-7) mention two approaches to explaining why objects (among other elements) can occupy different positions in the surface word order within a given language: the base generation approach and the movement approach. According to the base generation approach, the different positions which objects can occupy in the surface word order of a given language are related to the fact that objects can be generated in different positions. According to the movement approach, on the other hand, all objects are generated in the same position in a given language, and when objects occupy other positions in the surface word order, they have undergone movement. (The latter approach is, of course, the one employed in the discussion of object movement in this paper.) Corver and Van Riemsdijk (1994: 7) go on to state that "there is no consensus among proponents of the movement approach" as to what type of movement - A- or A'-movement - is involved in the case of object movement and that there are different analyses even for a single language (as illustrated by Bobaljik (1995) and Diesing's (1997) different analyses of object movement in German - see above). This question of A-movement vs. A'-movement is complicated further by what is referred to as "Webelhuth's Paradox" (see Webelhuth 1989), the observation that certain instances of object movement seem to simultaneously exhibit A- and A'-properties. A number of papers in 
Corver and Van Riemsdijk's volume address Webelhuth's Paradox and offer different solutions to it. One solution, originally proposed by Webelhuth (1989), is that there are not just A-positions and A'-positions but also "mixed positions" that exhibit both A- and A'properties, simultaneously. An alternative solution, offered by Mahajan (1990), is that there are no mixed positions and that, instead, movement operations (including object movement operations) that exhibit both A- and A'-properties, involve the successive application of an Amovement and an A'-movement; the A-movement yielding A-properties and the A'-movement yielding $\mathrm{A}^{\prime}$-properties.

Along these lines, Thráinsson (2001: 174-181) considers object movement in Icelandic, German, Yiddish and Dutch in terms of a number of diagnostics for A-vs.-A' movement, asking whether or not these movements (i) are clause-bounded, (ii) license parasitic gaps, (iii) influence binding relations, (iv) induce weak crossover violations, and (v) are related to Case in some way. Thráinsson concludes that object movement in all of these languages exhibits both A- and A'-properties (to a greater or lesser extent) and that, therefore, it is not clear that this is a good diagnostic for distinguishing OS from Scrambling. ${ }^{25}$ If it is true that A'movement necessarily involves prior A-movement, as proposed by Mahajan (see above), then the question of whether Afrikaans object movement is OS or Scrambling becomes irrelevant, as even A'-Scrambling would include a prior A-movement of the object into Spec,AgrOP, i.e.,true OS in the sense of BandT (1998).

Finally, it is interesting to note that just as the existence of TECs in Afrikaans is problematic for Koeneman's (2000) theory of verb movement (see section 3), so is the existence of OSCs in this language. Recall that if Afrikaans has V-to-C movement but not V-to-I movement, as Koeneman claims, then this language projects TP but not AgrP, under Koeneman's theory. Under the assumption that at least two functional projections are needed in the IP-complex in order to generate OSCs (see BandT 1998: 53), Koeneman incorrectly predicts that Afrikaans should not allow OSCs. It should be noted that Koeneman (p.c.) is not convinced that Afrikaans allows OS. On his view, the object movement constructions found in this language are instances of Scrambling. However, on the basis of the discussion of the OS- vs. -Scrambling debate in this section, I maintain that Afrikaans does indeed allow true OSCs. 


\section{Conclusion}

This paper has provided evidence for the existence of TECs and OSCs in Afrikaans. Given that only [+SIP] languages have the phrase structure to accommodate these two construction types, the paper has also provided evidence for a [+SIP] setting in Afrikaans. The contribution of this paper is twofold in that (i) it adds to the inventory of languages investigated in terms of the SIP, a parameter that has the desirable property of linking superficially disparate properties to each other, and (ii) it adds to the relatively small but growing body of literature on syntactic properties of Afrikaans (specifically within generative linguistics). Showing that TECs and OSCs are allowed in Afrikaans, of course, constitutes a mere starting point for indepth investigation into the syntactic and semantic properties of these construction types in Afrikaans. In my view, such investigation is necessary for a better understanding of these construction types in general, as some of the properties of these construction types in Afrikaans appear to be unique. Consider, for example, the fact that (to my knowledge) in any given language the object shift of an old-information object-NP is either prohibited (in [-SIP] languages such as English - see example (2c)) or obligatory (in [+SIP] languages such as Icelandic - see example (3c)) and that, in contrast, in Afrikaans such object shift appears to be optional (cf. the grammaticality of both (27a) and (27b), neither of which is marked). Hopefully, this paper suggests avenues to be explored in future research regarding the syntactic and semantic nature of TECs and OSCs in general and in Afrikaans specifically.

\section{Notes}

1. I would like to thank two anonymous reviewers for their helpful suggestions, as well as Johan Oosthuizen for stimulating (and inspiring) discussions, and Jonathan Bobaljik, Hans den Besten and Olaf Koeneman for their (always prompt and always valuable) e-mail replies to my questions. Any errors that remain are, of course, my own.

2. See section 2.2 below in which I argue that the more recent proposal for the abandonment of AgrSP and AgrOP does not negatively affect the validity of Thráinsson's SIP or BandT's proposal as set out in the current section. 
3. This statement is not entirely accurate, since the authors listed here do in fact allow the subject of a transitive verb to remain VP-internal under certain circumstances, namely when the object has left the VP. I will not consider this complication here.

4. BandT (1998: 53, footnote 17) follow researchers such as Déprez (1989, 1994), Bobaljik and Jonas (1996) and Josefsson (1992) in "treating pronoun shift as a distinct phenomenon from the shift of full DPs". Thráinsson (2001) also discusses some of the differences between the leftward movement of weak, unstressed pronouns (which is found in all Germanic languages except English - see Holmberg (1986) and Vikner (1995)) and what is referred to as "object shift" in this paper and in BandT (1998).

5. One reviewer noted that in West-Germanic studies, what BandT call "object shift" is called "scrambling" and what BandT call "scrambling" is called "focus scrambling". Because the current paper is set in the framework provided by BandT (1998), I will use the term "object shift" as they use it (i.e., as it is defined in this paragraph).

6. Verb raising in V2 environments involves movement of the verb into $\mathrm{C}$ (the head of the complementizer phrase). Because V2 movement (i.e., V-to-C movement) is not related to the functional categories in the IP-complex, it is not related to the setting of the SIP and will not be discussed here.

7. See section 2.2 in which I argue that the more recent proposal for a light verb projection ( $v \mathrm{P})$ above VP does not negatively affect the validity of BandT's theory of verb movement.

8. One reviewer noted that it is unsurprising that English does not allow the third person singular $-s$ to co-occur with the past tense morpheme $-(e) d$, since in all Germanic languages the third person singular agreement affix is restricted to the present tense. It might thus be that the only reason why English does not exhibit multiple inflectional morphemes is because it only has an overt agreement marker for third person singular, and third person singular agreement markers never co-occur with tense markers in Germanic languages. Even if this is the case, it does not provide evidence for a [+SIP] setting in English. Instead, it simply means that morphology offers no indication as to the setting of the SIP in English (see section 2.3 below for a similar argument regarding Afrikaans morphology). Even though the diagnostic of multiple inflectional morphemes is not useful in determining the setting of the SIP in English, the other three diagnostics mentioned in Table 1, are: the fact that the verb remains in VP in non-V2 environments shows that English must be a [-SIP] language, and the fact that 
both TECs and OSCs are ungrammatical in English, is consistent with this [-SIP] setting.

9. The central claim of the PISH is that "the [theta-position - SC] of arguments should be within the projections of the heads to which they are thematically related" (Hornstein et al. 2005: 110).

10. The reader is referred to Hornstein et al. (2005: chapter 3) for a summary of the motivations for and content of the proposal for $v \mathrm{P}$, as well as a description of the different types of verbs mentioned here.

11. The assumption that Afrikaans, Dutch, and German are underlyingly SOV is based on the traditional approach to headedness, according to which some languages are underlyingly SOV while others are underlyingly SVO (see, for example, Koster (1975) regarding Dutch). It should be noted that this assumption is no longer taken for granted and that some researchers follow Kayne (1994) in assuming that all languages are underlyingly SVO and that non-SVO constructions are derived via movement (see, for example, Zwart (1993) regarding Dutch). However, since the tension between these two proposals has not been resolved and the SOV-analysis has not been abandoned on a large scale within generative syntax, assuming that Afrikaans is an SOV language is, in my opinion, not controversial.

12. This problem of determining whether or not there is verb movement independent of V2-movement to C, exists for all SOV V2 languages (BandT 1998: 66).

13. Note that modals and the copula wees are not unique in this respect; there are some other verbs for which past tense can also be indicated by a stem change. However (as explained directly below), for the purposes of this paper it does not matter exactly how and where tense is marked by an affix in Afrikaans, since this language does not have any overt agreement morphemes.

14. At issue here are sentence-medial - i.e., non-topicalized - adverbs. Topicalized adverbs will, of course, precede both the subject and the object: for example, compare $[O p \text { die strand }]_{A D V}$ het [iemand] $]_{S U B J}$ gister ['n vuur] ${ }_{O B J}$ gemaak to the sentences in (16).

15. See, however, Verrips and Weissenborn (1992) (amongst others) who offer evidence from L1 acquisition that children acquire V-to-I movement long before they have acquired the relevant morphological distinctions that are supposed to act as triggers for 
the acquisition of this movement under morphology-driven approaches (such as that of Koeneman).

16. Koeneman's analysis of V-to-C movement is incompatible with the view that subjectinitial main clauses are IPs/AgrSPs. Therefore, he must assume, like BandT (see section 2.3), that subject-initial main clauses are CPs and, consequently, that subjectinitial main clauses are V2 environments in V2 languages (Koeneman 2000: 10, footnote 5). It follows that in V2 languages, the position of the verb in subject-initial main clauses indicates the presence/absence of V-to-C movement rather than V-to-I movement.

17. This means that BandT (1998) and Koeneman (2000) make opposite predictions regarding the presence/absence of non-V2 verb movement in Afrikaans. As explained in section 2.3, there is, unfortunately, at this stage no independent test for the presence/absence of non-V2 verb movement in SOV V2 languages such as Afrikaans, if one assumes (as I do here) that VP and IP/AgrP are head-final in these languages.

18. See note 5 regarding terminology.

19. See Czepluch (1990), though, for data from Icelandic that are taken to indicate that the direct object can indeed move over the subject in Icelandic under specific circumstances (Thráinsson 2001: 198, note 12).

20. At issue here are non-topicalized direct objects. Topicalized direct objects will, of course, precede the subject: for example, compare [Die boeke] ${ }_{O B J}$ het [Jan] $]_{S U B J}$ nie gister gelees nie to the sentences in (28).

21. Example (30a) is taken from Diesing (1997:403) and examples (30b) and (30c) are taken from Collins and Thráinsson (1996), as cited and discussed in Bobaljik (2002: 243). In these examples, the abbreviations DAT and ACC indicate Dative Case and Accusative Case, respectively.

22. Similarly, Thráinsson (2001: 200, note 26) refers to a Dutch example in Neeleman (1994: 394) which "arguably does not involve Scrambling of an object across an indirect object but rather the base generated order DO-prepositional IO, as [Neeleman - SC] himself points out in note 3".

23. Though, subsequently, McCloskey (2000) has presented data from West Ulster English that seem to involve $\mathrm{A}^{\prime}$-movement that licenses floating quantifiers. 
24. The sentences in (31) are the Afrikaans translations of the German and Dutch sentences used by Bobaljik (1995: 134) to show that object movement licenses floating quantifiers in these languages.

25. Note that Diesing (1997: 407, note 23) also admits that, although Yiddish and German Scrambling exhibits A'-movement properties, it also exhibits some A-movement properties.

\section{References}

Alexiadou, A. and E. Anagnostopoulou. 1997. Postverbal subjects. Manuscript, Tilburg and MIT.

Anagnostopoulou, E. 2003. The syntax of ditransitives: Evidence from clitics. Berlin: Mouton de Gruyter.

Bobaljik, J.D. 1995. Morphosyntax: The syntax of verbal inflection. Doctoral dissertation, MIT.

Bobaljik, J.D. 2002. A-chains at the PF-interface: Copies and 'covert' movement. Natural Language and Linguistic Theory 20: 197-267.

Bobaljik, J.D. and D. Jonas. 1996. Subject positions and the roles of TP. Linguistic Inquiry 27 (2): 195-236.

Bobaljik, J.D. and H. Thráinsson. 1998. Two heads aren't always better than one. Syntax 1 (1): 37-71.

Chomsky, N. 1991. Some notes on economy of derivation and representation. In R. Freidin (ed). Principles and parameters in comparative grammar. Cambridge: MIT Press. pp. 417-454.

Chomsky, N. 1995. The minimalist program. Cambridge: MIT Press.

Collins, C. and H. Thráinsson. 1996. VP-internal structure and object shift in Icelandic. Linguistic Inquiry 27: 391-444.

Conradie, S. 2005. Verb movement parameters in Afrikaans: Investigating the Full Transfer Full Access hypothesis. Doctoral dissertation, McGill University.

Conradie, S. 2006. Investigating the acquisition of the Split-IP parameter and the V2 parameter in L2 Afrikaans. Second Language Research 22 (1): 64-94.

Corver, N. and H. van Riemsdijk (eds). 1994. Studies on scrambling. Movement and nonmovement approaches to free word-order phenomena. Berlin: Mouton de Gruyter. 
Czepluch, H. 1990. Word order variation in a configurational language: Against a uniform Scrambling account in German. In W. Abraham, W. Kosmeijer, and E. Reuland (eds). Issues in Germanic syntax. Berlin: De Gruyter. pp. 163-195.

Déprez, V. 1989. On the typology of syntactic positions and the nature of chains. Move $\alpha$ to the specifier of functional projections. Doctoral dissertation, MIT.

Déprez, V. 1994. Parameters of object movement. In N. Corver and H. van Riemsdijk (eds). Studies on scrambling. Movement and non-movement approaches to free word-order phenomena. Berlin: Mouton de Gruyter. pp. 101-152.

Diesing, M. 1997. Yiddish VP order and the typology of object movement in Germanic. Natural Language and Linguistic Theory 15: 369-427.

Donaldson, B.C. 1993. A grammar of Afrikaans. Berlin and New York: Mouton de Gruyter.

Holmberg, A. 1986. Word order and syntactic features in the Scandinavian languages and English. Doctoral dissertation, University of Stockholm.

Hornstein, N., J. Nunes, and K.K. Grohmann. 2005. Understanding Minimalism. Cambridge: Cambridge University Press.

Iatridou, S. 1990. About Agr(P). Linguistic Inquiry 21: 551-577.

Josefsson, G. 1992. Object shift and weak pronominals in Swedish. Working Papers in Scandinavian Syntax 49: 59-94.

Kayne, R. 1994. The antisymmetry of syntax. Cambridge: MIT Press.

Koeneman, O. 2000. The flexible nature of verb movement. Doctoral dissertation, Utrecht University.

Koster, J. 1975. Dutch as an SOV language. Linguistic Analysis 1 (2): 111-136.

Mahajan, A. 1990. The A/A' distinction and movement theory. Doctoral dissertation, MIT.

McCloskey, J. 2000. Quantifier float and wh-movement in an Irish English. Linguistic Inquiry 31: $57-84$.

Neeleman, A. 1994. Scrambling as a D-structure phenomenon. In N. Corver and H. van Riemsdijk (eds). Studies on scrambling. Movement and non-movement approaches to free word-order phenomena. Berlin: Mouton de Gruyter. pp. 387-429.

Pollock, J.-Y. 1989. Verb movement, universal grammar, and the structure of IP. Linguistic Inquiry 20: 365-424.

Rizzi, L. 1990. Relativized Minimality. Cambridge: MIT Press.

Rohrbacher, B.W. 1994. The Germanic VO languages and the full paradigm: A theory of $V$ to I raising. Doctoral dissertation, University of Massachusetts. 
Rohrbacher, B.W. 1999. Morphology-driven syntax. A theory of $V$ to I raising and pro-drop. Amsterdam and Philadelphia: John Benjamins.

Thráinsson, H. 1996. On the (non-)universality of functional categories. In W. Abraham, S.D. Epstein, H. Thráinsson, and C.J.-W. Zwart (eds). Minimal Ideas. Amsterdam: Benjamins. pp. 253-281.

Thráinsson, H. 2001. Object shift and scrambling. In M. Baltin and C. Collins (eds). The handbook of contemporary syntactic theory. Oxford: Blackwell. pp. 148-202.

Verrips, M. and J. Weissenborn. 1992. Routes to verb placement in early German and French: the independence of finiteness and agreement. In J. Meisel (ed). The acquisition of verb placement. Functional categories and V2 phenomena in language acquisition. Dordrecht: Kluwer. pp. 283-331

Vikner, S. 1995. Verb movement and expletive subjects in the Germanic languages. Oxford: Oxford University Press.

Vikner, S. 1997. The interpretation of Object Shift, Optimality Theory, and Minimalism. Working Papers in Scandinavian Syntax 60: 1-24.

Webelhuth, G. 1989. Syntactic saturation phenomena and the Modern Germanic languages. Doctoral dissertation, University of Massachusetts.

White, L. 1991. Adverb placement in second language acquisition: Some effects of positive and negative evidence in the classroom. Second Language Research 7: 133-161.

Zwart, C.J.-W. 1993. Dutch syntax: A minimalist approach. Doctoral dissertation, University of Groningen. 